\title{
Prevalence and antenatal determinants of orofacial clefts in Benin City, Edo State Nigeria
}

\author{
Omo-Aghoja VW', Omo-Aghoja L O², Ugboko VI ${ }^{3}$, Obuekwe ON ${ }^{4}$, Saheeb BDO ${ }^{4}$, Feyi-Waboso p ${ }^{5}$. \\ Onowhakpor $\mathbf{A}^{2}$ \\ ${ }^{1}$ Department of Oral and Maxillofacial Surgery, Central Hospital, Sapele, Nigeria; \\ ${ }^{2}$ Department of Obstetrics and Gynaecology, College of Health Sciences, Delta State University, Abraka, Nigeria; \\ ${ }^{3}$ Department of Oral and Maxillofacial Surgery, College of Medicine, Obafemi Awolowo University, Ile-Ife, \\ Nigeria; \\ ${ }^{4}$ Department of Oral and Maxillofacial Surgery, College of Medical Sciences, University of Benin, Benin City, \\ Nigeria and \\ ${ }^{5}$ Department of Obstetrics and Gynaecology, Abia State University Teaching Hospital, Aba, Nigeria.
}

Omo-Aghoja VW, Omo-Aghoja LO, Ugboko VI, Obuekwe ON, Saheeb BDO, Feyi-Waboso P. Onowhakpor A

Prevalence and antenatal determinants of orofacial clefts in Benin city, Edo State Nigeria. Tanz Dent J 2010; 16(1):9-17

\begin{abstract}
Aim: This study was undertaken to determine the prevalence and antenatal determinants of orofacial clefts in Southern Nigeria. Methods: A cross-sectional descriptive study undertaken at the Maxillofacial Units of the University of Benin Teaching Hospital and the Central Hospital, Benin City, Nigeria respectively. The prevalence and antenatal determinants of cleft lip and palate were determined. Result: Cleft lip and palate were often encountered in clinical practice in Benin City with a prevalence of $1.35 \%$. The results showed that orofacial clefts were commoner in females and that the combined unilateral cleft lip and palate was the commonest entity encountered amongst the cases. The following risk factors were associated with the risk of development of cleft lip and palate: Paternal age >40years, maternal age >35years, genetic/family history, low socio-economic status, alcohol consumption and indulgence in the intake of herbal medications in pregnancy. Conclusion: Public health education programmes and advocacy activities geared towards raising awareness of the identified risk factors for the development of cleft lip and or cleft palate would go a long way to obviate the occurrence and reduce the burden.
\end{abstract}

Key Words: $\quad$ Prevalence, Antenatal determinants, orofacial clefts, Southern Nigeria

Correspondence: Dr. Omo-Aghoja L O, Dept. of Obstetrics and Gynaecology, College of Health Sciences, Delta State University, Abraka, Delta State, Nigeria. Tel: 234 8023435599, 234 8039377043, E mail: eguono_2000@yahoo.com, losuakpor@gmail.com

\section{Introduction}

Available evidence indicates that cleft lip with or without cleft palate, is the most common serious congenital anomaly that affects the orofacial region in humans (1). These deformities can be seen, felt and heard hence they constitute a serious affliction to those who have them and their families.

Reports $(1,2)$ show that there is higher incidence of cleft in the Asians than in the Caucasians and least amongst the black race. The worldwide incidence is reported to be 1 in 700 among Asians and 1.7/1000 live births amongst Japanese. It is 3.6/1000 live births in a group of American Indians and 1/1000 live births amongst Caucasians. Boys are affected more than girls with a ratio of about 3:2 (1). Clefts of the lip are more frequent in boys $(60 \%)$ while isolated clefts of the palate are more frequent in girls (59\%) (3).

The exact etiology of cleft lip and palate is uncertain, however studies $(1,3)$ suggest that it is multifactorial with both genetic and environmental factors implicated. In $20-30 \%$ of patients with left sided cleft there are associated hereditary factors (4). The probability of a child having cleft lip is reported to be $2 \%$ if one of the parents has a cleft but this increases to $14 \%$ in subsequent children if a child already has a cleft. If neither of the parents has cleft but one child has it, the chances of another child having a cleft are $4.5 \%$ and this increases 2, 4 and 40 times in third, second and first degree relatives of affected patients (2). On the other hand, several reports $(1,3,4)$ have associated a number of environmental factors with the causation of cleft. Such factors include vitamin deficiencies particularly vitamins $\mathrm{A}$ and $\mathrm{B}$, viral agents such as the rubella virus and infestation with toxoplasma gondii — the causative agent of toxoplasmosis. Others are exposure to irradiation, 
cortisone excess and ingestion of drugs like thalidomide, steroids, anticonvulsants (phenytoin), diazepam, amino pectin and nitrogen mustard, subjection to hypoxic situations, ACTH excess, maternal alcohol consumption and cigarette smoking, all in pregnancy especially in the first trimester $(1,3,4)$.

Although the reported incidences of cleft lip and palate in the few published Nigerian works (5-7) are less than the Caucasian and Oriental figures, the management and care of the cleft patient still constitutes a substantial proportion of the workload of the Nigerian maxillofacial surgeon and allied specialties. Yet, there are no specific programmes targeted at this group in order to reduce the incidence and offer comprehensive management strategies geared towards optimizing outcome of treatment. The purpose of this study therefore, was to determine the prevalence and associated risk factors of cleft lip and palate in UBTH and Central Hospital, both in Benin City, Nigeria. We believe that the findings of this study is capable of identifying useful interventions for designing programs that will lead to a reduction in the burden of orofacial cleft in Nigeria.

\section{Methodology}

It was a cross-sectional descriptive study that was undertaken from November 12006 to October $31^{\text {st }}$ 2007. The study was conducted at the Maxillofacial Units of the University of Benin Teaching Hospital (UBTH) and the Central Hospital $(\mathrm{CH})$, Benin City respectively. UBTH is the largest tertiary center with 575 bed spaces and $\mathrm{CH}$ is the largest secondary health institution with 435 bed spaces, in Edo state of Nigeria. They serve as referral centers for Edo, Delta, Ondo and Kogi States with an overall approximate population size of about 14 million people (2006 National population census).

The sample size of 60 was determined using Taylor's Formula (8) and the maximum known prevalence of $0.4 / 1000$ live births reported in Nigerians (5), although all 68 consenting patients with Cleft defect seen in the Hospitals within the study period were included in the study. Patients who declined giving their consent and those with previous cleft repair presenting for follow up were excluded from the study.

A pre-tested and validated study protocol was used for the data collection. The study protocol which was filled by trained interviewers elicited the following information; socio-demographic profile of the patients and parents, family history surveying both paternal and maternal aspects particularly family history of cleft, dietary/nutritional history, patient's antenatal and delivery history. Specifically, the protocol explored the following antenatal events parental history of alcohol ingestion, cigarette smoking, cooking method, drug use during pregnancy and exposure to irradiation.

Approval for this study was obtained from the Ethics committee of the University of Benin Teaching Hospital. The rights of patients to participate or not was respected, and the study was carefully explained to the patients or their parents and their informed consent obtained before they were recruited into the study.

All information obtained was recorded on the data collection sheet designed for the study. The coded data were then fed into the computer using the SPSS statistical software and analysis was conducted. This consisted of univariate and bivariate analysis and comparisons of identified relationships. Test of the statistical significance was based on $95 \%$ confidence interval using Chi -square test with the Yates or Fischer exact correction where applicable. Odds ratio and confidence interval was then calculated to determine the association between the risk factors and cleft lip and palate.

\section{Results}

Overall, 5,037 patients presented at the Dental Centres of UBTH and $\mathrm{CH}$ Benin City for treatment during the study period, and 68 of these patients had cleft lip and palate giving a prevalence rate of $1.35 \%$. There were 33 males $(48.5 \%)$ and 35 females $(51.5 \%)$ whose ages (table 1) ranged from 5 days to 37 years (mean \pm SD; $3.22 \pm 6.82$ years). The mean age for males was $2.9 \pm 6.8$ years while that of females was $2.9 \pm 7$ years, this difference is not statistically significant $(\mathrm{P}>0.05))$. Forty patients $(58.4 \%)$ were children less than a year with $14(20.1 \%)$ less than a month old. Three adult clefts were also seen during the study period (two females and a male). Over half of the cases $(58.8 \%)$ were delivered at maternity homes, while home deliveries accounted for 5 cases (8.7\%), 8 patients $(11.8 \%)$ were delivered at Traditional birth attendants' homes and 15 patients $(22.1 \%)$ at general and teaching hospitals. 
Table 1:Distribution of patients with clefts by age-group, types of clefts and gender

\begin{tabular}{lllllll}
\hline Variables & \multicolumn{4}{c}{ Gender } & \multicolumn{2}{c}{ Total } \\
\hline & \multicolumn{2}{c}{ Male } & \multicolumn{1}{c}{ Female } & & \\
\hline Age group (years) & $\mathrm{n}$ & $\%$ & $\mathrm{n}$ & $\%$ & $\mathrm{n}$ & $\%$ \\
$<1$ & 19 & $(27.9)$ & 21 & $(30.9)$ & 40 & $(58.4)$ \\
$1-4$ & 6 & $(8.8)$ & 8 & $(11.8)$ & 14 & $(20.6$ \\
$5-8$ & 5 & $(7.4)$ & 2 & $(2.9)$ & 7 & $(10.3)$ \\
$9-12$ & 2 & $(2.9)$ & 2 & $(2.9)$ & 4 & $(5.9)$ \\
$>12$ & 1 & $(1.5)$ & 2 & $(2.9)$ & 3 & $(4.4)$ \\
Total & 33 & $(48.5)$ & 35 & $(51.5)$ & 68 & $(100)$ \\
& & & & & & \\
Unilateral cleft lip and palate & & & & & & \\
URL & 2 & $(2.9)$ & 0 & $(0)$ & 2 & $(2.9)$ \\
URLA & 1 & $(1.5)$ & 6 & $(8.8)$ & 7 & $(10.3)$ \\
URLAP & 5 & $(7.3)$ & 6 & $(8.8)$ & 11 & $(16.2)$ \\
ULL & 1 & $(1.5)$ & 1 & $(1.5)$ & 2 & $(2.9)$ \\
ULLA & 3 & $(4.4)$ & 0 & $(0)$ & 3 & $(4.4)$ \\
ULLAP & 10 & $(4.5)$ & 5 & $(7.3)$ & 15 & $(22.1)$ \\
Total & $\mathbf{2 2}$ & $\mathbf{( 5 5 . 0 )}$ & $\mathbf{1 8}$ & $\mathbf{( 4 5 . 0 )}$ & $\mathbf{4 0}$ & $(\mathbf{1 0 0 . 0})$ \\
& & & & & & \\
Bilateral cleft lip and palate & & & & & & \\
BLA & 0 & $(0)$ & 2 & $(2.9)$ & 2 & $(2.9)$ \\
BLAP & 4 & $(5.9)$ & 3 & $(4.4)$ & 7 & $(10.3)$ \\
BLABP & 2 & $(2.9)$ & 1 & $(1.5)$ & 3 & $(4.4)$ \\
Total & $\mathbf{6}$ & $\mathbf{( 5 0 . 0 )}$ & $\mathbf{6}$ & $\mathbf{( 5 0 . 0 )}$ & $\mathbf{1 2}$ & $(\mathbf{1 0 0 . 0})$ \\
Other clefts & & & & & & \\
SMC & & & & & & \\
IP & 1 & $(1.5)$ & 0 & $(0)$ & 1 & $(1.5)$ \\
Total & 4 & $(5.9)$ & 11 & $(16.2)$ & 15 & $(22.1)$ \\
All types of clefts & $\mathbf{5}$ & $\mathbf{( 3 1 . 2 )}$ & $\mathbf{1 1}$ & $(\mathbf{6 8 . 8})$ & $\mathbf{1 6}$ & $(\mathbf{1 0 0 .}$ \\
& & & & & & \\
& $\mathbf{3 3}$ & $\mathbf{( 4 8 . 5 )}$ & $\mathbf{3 5}$ & $\mathbf{( 5 1 . 5 )}$ & $\mathbf{6 8}$ & $(\mathbf{1 0 0})$ \\
\hline & & & & & &
\end{tabular}

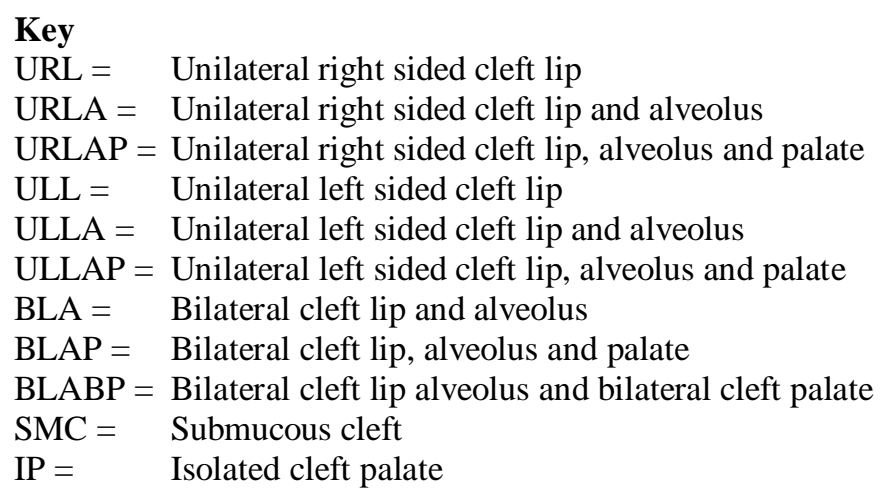

Of the 68 patients, there were 40 cases $(58.8 \%)$ of unilateral cleft lip with or without cleft palate, 12 cases $(17.6 \%)$ of bilateral cleft lip with or without cleft palate, 15 (22.1\%) of isolated cleft palate and 1 case $(1.5 \%)$ of submucous cleft (table 1). The unilateral clefts were equally distributed on the right and left sides of the face but had more male distribution (23 cases). While equal distribution of bilateral cases was observed amongst male and female patients (tables 1,2), isolated cleft palate in contrast, had more female distribution (11 females and 4 males). Overall, thirty six patients $(52.9 \%)$ had combined cleft lip and palate defects, 4 patients (5.9\%) had isolated cleft lip, 12 patients $(17.6 \%)$ had cleft lip and alveolus while 15 patients $(22.1 \%)$ had isolated cleft palate. Of the 12 patients (17.4\%) with bilateral cleft, 10 patients (14.9\%) had combined cleft lip and cleft palate. The single case of submucous 
cleft palate presented with bifid uvula, palatal bone dehiscence and covering oral epithelium.

The leading ethnic groups were the Urhobo's (15 cases, 22.1\%), the Binis and the Esan patients (11cases, 16.2\% respectively). Overall, 31 patients
(45.6\%) were from both Edo and Delta state each, while the Yoruba's were $6(8.8 \%)$. Forty seven patients $(69.1 \%)$ in this study were of low socio economic class while twenty patients $(29.4 \%)$ were middle classed. One case $(1.5 \%)$ belonged to the upper social class (table 3 ).

Table 2: Age and gender distribution of cleft types

\begin{tabular}{|c|c|c|c|c|c|c|c|c|c|c|c|c|c|c|c|}
\hline \multicolumn{16}{|c|}{ CLEFT TYPE } \\
\hline & \multicolumn{2}{|c|}{ ULA } & \multicolumn{2}{|c|}{ ULAP } & \multicolumn{2}{|c|}{ BLA } & \multicolumn{2}{|c|}{ BLAP } & \multicolumn{2}{|c|}{ SMC } & \multicolumn{2}{|l|}{ IP } & \multicolumn{2}{|c|}{ TOTAL } & \multirow[b]{2}{*}{ p-value } \\
\hline & $\mathbf{n}$ & $\%$ & $\mathbf{n}$ & $\%$ & $\mathbf{n}$ & $\%$ & $\mathbf{n}$ & $\%$ & $\mathbf{n}$ & $\%$ & $\mathbf{n}$ & $\%$ & $\mathbf{n}$ & $\%$ & \\
\hline \multicolumn{16}{|c|}{ Age (years) } \\
\hline$<1$ & 12 & (17.6) & 13 & (19.1) & 2 & (2.9) & 8 & (11.7) & 0 & (0) & 5 & $(7.8)$ & 40 & $(58.9)$ & \\
\hline $1-4$ & 0 & (0) & 9 & (13.2) & 0 & (0) & 1 & (1.5) & 0 & (0) & 4 & $(5.9)$ & 14 & (20.6) & \\
\hline $5-8$ & 0 & (0) & 4 & (5.9) & 0 & (0) & 0 & (0) & 0 & (0) & 3 & (4.4) & 7 & $(10.3)$ & \\
\hline $9-12$ & 0 & (0) & 0 & (0) & 0 & (0) & 1 & (1.5) & 1 & $(1.5)$ & 2 & (2.9) & 4 & (5.9) & \\
\hline$>12$ & 2 & (2.9) & 0 & (0) & 0 & $(0)$ & 0 & (0) & 0 & (0) & 1 & $(1.5)$ & 3 & $(4.4)$ & 0.003 \\
\hline \multicolumn{16}{|c|}{ Sex distribution } \\
\hline Male & 7 & $(10.3)$ & 15 & (22.1) & 0 & (0) & 6 & $(8.8)$ & 1 & $(1.5)$ & 4 & (5.9) & 33 & $(48.5)$ & \\
\hline Female & 7 & (10.3) & 11 & (16.2) & 2 & (2.9) & 4 & (5.9) & 0 & $(0)$ & 11 & $(16.2)$ & 35 & $(51.5)$ & 0.204 \\
\hline
\end{tabular}

Of the 68 patients who presented during the study period, the ages of 61 fathers $(89.7 \%)$ and 62 mothers $(91.2 \%)$ were obtained while others failed to volunteer such information. The ages of the fathers ranged from 20 years to 70 years with a median of 37 years (mean $\pm \mathrm{SD} ; 37.13 \pm 8.51$ years), while that of the mothers (table 4) ranged from 15 years to 45 years with a median of 28 years (mean \pm SD; $29.19 \pm$ 5.86 years). The difference was statistically significant $(\mathrm{p}<0.05)$.
Among the various paternal age groups, $41.2 \%$ were within the 30-39 year age group and they accounted for a significantly high proportion of patients $(22.1 \%)$ with unilateral cleft lip and palate while a greater percentage of mothers (54.4\%) where in the 25-34 age group and they accounted for a significantly high proportion of patients $(14.5 \%)$ with isolated cleft palate.

Table 3:

Ethnic and social class distribution of cleft types

\begin{tabular}{|c|c|c|c|c|c|c|c|c|c|c|c|c|c|c|c|}
\hline \multicolumn{16}{|c|}{ CLEFT TYPE } \\
\hline & \multicolumn{2}{|c|}{ ULA } & \multicolumn{2}{|c|}{ ULAP } & \multicolumn{2}{|c|}{ BLA } & \multicolumn{2}{|c|}{ BLAP } & \multicolumn{2}{|c|}{ SMC } & \multicolumn{2}{|c|}{ IP } & \multicolumn{3}{|c|}{ TOTAL } \\
\hline & $\mathbf{n}$ & $\%$ & $\mathbf{n}$ & $\%$ & $\mathbf{n}$ & $\%$ & $\mathbf{n}$ & $\%$ & $\mathbf{n}$ & $\%$ & $\mathbf{n}$ & $\%$ & $\mathbf{n}$ & $\%$ & $\begin{array}{l}\text { p- } \\
\text { value }\end{array}$ \\
\hline \multicolumn{16}{|c|}{ Ethnic distribution } \\
\hline Esan & 4 & $(5.9)$ & 4 & $(5.9)$ & 0 & (0) & 1 & $(1.5)$ & 0 & (0) & 2 & $(2.9)$ & 11 & (16.2) & \\
\hline Bini & 4 & $(5.9)$ & 3 & (4.4) & 0 & (0) & 4 & $(5.9)$ & 0 & (0) & 0 & (0) & 11 & (16.2) & \\
\hline Edo & 1 & $(1.5)$ & 3 & $(4.4)$ & 0 & (0) & 2 & $(2.9)$ & 0 & (0) & 3 & $(4.4)$ & 9 & (13.2) & \\
\hline Urhobo & 2 & (2.9) & 8 & (11.8) & 1 & (1.5) & 1 & $(1.5)$ & 1 & $(1.5)$ & 2 & $(2.9)$ & 15 & $(22.1)$ & \\
\hline Delta & 0 & $(0)$ & 8 & (5.9) & 1 & (1.5) & 2 & $(2.9)$ & 0 & (0) & 5 & $(7.3)$ & 16 & $(23.5)$ & \\
\hline Yoruba & 3 & $(4.4)$ & 0 & $(0)$ & 0 & $(0)$ & 0 & $(0)$ & 0 & (0) & 3 & $(4.4)$ & 6 & $(8.8)$ & 0.179 \\
\hline \multicolumn{16}{|l|}{ Social class } \\
\hline I(High) & 0 & $(0)$ & 1 & $(1.5)$ & 0 & (0) & 0 & (0) & 0 & (0) & 0 & (0) & 1 & $(1.5)$ & \\
\hline II(Middle) & 3 & $(4.4)$ & 5 & $(7.4)$ & 1 & (1.5) & 4 & $(5.9)$ & 1 & (1.5) & 6 & $(8.8)$ & 20 & (29.4) & \\
\hline III(Low) & 11 & (16.2) & 20 & (29.4) & 1 & $(1.5)$ & 6 & $(8.8)$ & 0 & $(0)$ & 9 & (13.2) & 47 & $(69.1)$ & 0.689 \\
\hline
\end{tabular}


A family history of cleft was obtained in 9 patients (13.2\%) with cleft palate either in isolation, or with cleft lip. Of the 61 fathers and 62 mothers, there were positive family history in one father $(1.5 \%)$ and 4 mothers $(5.9 \%)$ respectively. Additionally, there was a positive family history from $6(8.8 \%)$ maternal relatives and one paternal relative. Four patients $(5.9 \%)$ had siblings with a cleft. Bilateral cleft lip and palate was the cleft type noted to be most commonly associated with family history (5 cases) while patients with cleft lip alone or cleft lip and alveolus had no family history of cleft. Three mothers had Van der woude syndrome and this was replicated amongst two of their children. Although nine patients had positive family history, some patients had multiple family history with the highest record of a patient whose mother had bilateral cleft lip, and also additional maternal and paternal family history of cleft lip and palate.

Thirty-seven patients $(54.4 \%)$ had a positive history of maternal illness during their pregnancy course with 17 (25\%) being febrile illness/malaria, followed by upper respiratory tract infection in 13 mothers $(19.1 \%)$. Others were abdominal pain in 4 cases (5.9\%), diarrhoea in 2 cases $(2.9 \%)$ and 1 case $(1.5 \%)$ of threatened abortion (table 6 ). A total of 40 mothers $(58.8 \%)$ ingested orthodox medications during their pregnancy and another 15 mothers $(22.1 \%)$ took herbal medications. Twenty two (32.4\%) of such mothers ingested routine antenatal hematinics, three mothers (4.4\%) took antibiotics while 3 others $(4.4 \%)$ ingested antimalarials. Other drugs taken include one each of primolut injection and franol while a significantly large number of mothers $(14.7 \%)$ took unspecified medications (table 5).
None of the mothers volunteered a positive history of cigarette smoking or tobacco consumption. However, majority of them (66.2\%) cooked with kerosene stove followed by firewood in $14(20.6 \%)$ cases and gas in $4(5.9 \%)$ cases (table 6). Thirty four patients $(50.0 \%)$ had their kitchens located outdoor, 30 (44.1\%) cooked indoors while kitchen location could not be ascertained in $4(5.9 \%)$ cases. This difference was not statistically significant $(\mathrm{p}>0.05)$. Eighteen mothers (26.5\%) ingested alcohol during their pregnancy with 9 cases (13.2\%) taking local gin, thus making local gin the most frequently ingested type. Seven mothers $(10.3 \%)$ suffered one form of trauma or the other while 13 mothers $(19.1 \%)$ had radiographic exposure during pregnancy. The highest incidence $(10.3 \%)$ of radiographic exposure was in the third trimester.

Of the study population, $6(8.8 \%)$ were products of multiple gestation with five sets of twins and a set of triplet. Among the twin pregnancies, there were 2 cases of monozygotic twinning and 3 cases of dizygotic twining. The only set of triplets was monozygotic. Of the affected dizygotic twins, 2 (2.9\%) were females and one was a male while the monozygotic twins were all boys. In all cases of multiple gestations, only one of each set was affected.

Majority of the patients $(92.6 \%)$ were delivered at term while one each of preterm birth (34 weeks) and postdated delivery (45 weeks) was recorded. The mean gestational age in this study was $37.64 \pm$ 1.82 weeks.

Table 4: Age distribution of Parents according to cleft types

\begin{tabular}{|c|c|c|c|c|c|c|c|c|c|c|c|c|c|c|c|}
\hline \multicolumn{16}{|c|}{ CLEFT TYPE } \\
\hline & \multicolumn{2}{|c|}{ ULA } & \multicolumn{2}{|c|}{ ULAP } & \multicolumn{2}{|c|}{ BLA } & \multicolumn{2}{|c|}{ BLAP } & \multicolumn{2}{|c|}{ SMC } & \multicolumn{2}{|l|}{ IP } & \multicolumn{2}{|c|}{ TOTAL } & \multirow[b]{2}{*}{ p-value } \\
\hline & $\mathbf{n}$ & $\%$ & $\mathbf{n}$ & $\%$ & $\mathbf{n}$ & $\%$ & $\mathbf{n}$ & $\%$ & $\mathbf{n}$ & $\%$ & $\mathbf{n}$ & $\%$ & $\mathrm{n}$ & $\%$ & \\
\hline \multicolumn{16}{|c|}{ Father's age (years) } \\
\hline $20-29$ & 4 & $(5.9)$ & 3 & (4.4) & 0 & (0) & 0 & (0) & 0 & (0) & 3 & (4.4) & 10 & (14.7) & \\
\hline $30-39$ & 4 & (5.9) & 15 & (22.1) & 0 & (0) & 4 & (5.9) & 0 & (0) & 5 & (7.3) & 28 & $(41.2)$ & \\
\hline $40-49$ & 4 & (5.9) & 6 & $(8.8)$ & 2 & (2.9) & 3 & (4.4) & 0 & (0) & 5 & (7.3) & 20 & $(29.4)$ & \\
\hline$>49$ & 0 & (0) & 0 & (0) & 0 & (0) & 2 & (2.9) & 0 & (0) & 1 & (1.5) & 3 & $(4.4)$ & 0.111 \\
\hline \multicolumn{16}{|c|}{ Mean age $=37.13$} \\
\hline \multicolumn{16}{|c|}{ Mother's age (years) } \\
\hline $15-24$ & 4 & $(5.9)$ & 4 & (5.9) & 0 & (0) & 0 & (0) & 0 & (0) & 2 & (2.9) & 12 & (17.6) & \\
\hline $25-34$ & 7 & $(10.3)$ & 14 & (20.6) & 1 & (1.5) & 5 & (7.3) & 0 & (0) & 10 & (14.7) & 37 & $(54.4)$ & \\
\hline $35-44$ & 1 & $(1.5)$ & 4 & $(5.9)$ & 1 & (1.5) & 4 & (5.9) & 0 & (0) & 2 & $(2.9)$ & 12 & (17.6) & \\
\hline$>44$ & 0 & (0) & 0 & (0) & 0 & (0) & 0 & (0) & 1 & (1.5) & 0 & (0) & 1 & $(1.5)$ & 0.000 \\
\hline \multicolumn{16}{|c|}{ Mean age $=29.19$} \\
\hline
\end{tabular}




\section{Discussion}

This study showed an overall prevalence rate of cleft lip and palate in the two Benin City hospitals to be $1.35 \%$. Interestingly from the literature search, it was difficult to locate any Nigerian study that documented the prevalence of cleft lip and palate amongst patients seen in any of our maxillofacial centers. The only study that reported on population incidence (prevalence at birth) was by Iregbulem (5) from Enugu in eastern Nigeria when he found a prevalence rate of $0.04 \%$ after he examined 21,624 consecutive infants born at the University of Nigeria Teaching Hospital over a 5-year period. However, in this study setting prevalence of $1.35 \%$ is at variance with other studies with a known range of $0.06 \%$ $0.2 \% \quad(9-10)$. The studies from which these prevalences were derived had larger sample sizes as compared to this study conducted on patients who attended the dental clinics.

Table 5:Cleft types and Pregnancy associated events

\begin{tabular}{|c|c|c|c|c|c|c|c|c|c|c|c|c|c|c|c|}
\hline \multirow{3}{*}{$\begin{array}{l}\text { Pregnancy } \\
\text { associated } \\
\text { events }\end{array}$} & \multicolumn{15}{|c|}{ CLEFT TYPE } \\
\hline & \multicolumn{2}{|c|}{ ULA } & \multicolumn{2}{|c|}{ ULAP } & \multicolumn{2}{|c|}{ BLA } & \multicolumn{2}{|c|}{ BLAP } & \multicolumn{2}{|c|}{ SMC } & \multicolumn{2}{|l|}{ IP } & \multicolumn{3}{|c|}{ TOTAL } \\
\hline & $\mathbf{n}$ & $\%$ & $\mathbf{n}$ & $\%$ & $\mathbf{n}$ & $\%$ & $\mathbf{n}$ & $\%$ & $\mathbf{n}$ & $\%$ & $\mathbf{n}$ & $\%$ & $\mathbf{n}$ & $\%$ & $\begin{array}{l}\text { p- } \\
\text { value }\end{array}$ \\
\hline \multicolumn{16}{|c|}{ Pregnancy type } \\
\hline Singleton & 13 & (19.1) & 24 & $(35.3)$ & 2 & (2.9) & 8 & $(11.8)$ & 1 & $(1.5)$ & 14 & (20.6) & 62 & (91.2) & \\
\hline Twin & 1 & $(1.5)$ & 2 & (2.9) & 0 & $(0)$ & 2 & (2.9) & 0 & (0) & 0 & $(0)$ & 5 & (7.3) & \\
\hline $\begin{array}{l}\text { Higher } \\
\text { order }\end{array}$ & 0 & (0) & 0 & $(0)$ & 0 & (0) & 0 & (0) & 0 & (0) & 1 & $(1.5)$ & 1 & (1.5) & 0.705 \\
\hline \multicolumn{16}{|c|}{ Cooking method } \\
\hline $\begin{array}{l}\text { Kerosene } \\
\text { stove }\end{array}$ & 7 & (10.3) & 17 & $(25.0)$ & 2 & (2.9) & 7 & (10.3) & 0 & (0) & 12 & (17.6) & 45 & $(66.2)$ & \\
\hline Firewood & 4 & (5.9) & 8 & (11.8) & 0 & (0) & 2 & $(2.9)$ & 0 & (0) & 1 & $(1.5)$ & 14 & (20.6) & 0.026 \\
\hline \multicolumn{16}{|c|}{ Maternal illness } \\
\hline $\begin{array}{l}\text { Malaria/ } \\
\text { fever }\end{array}$ & 2 & (2.9) & 9 & $(13.2)$ & 0 & (0) & 3 & (4.4) & 0 & (0) & 3 & $(4.4)$ & 17 & $(25.0)$ & \\
\hline URTI & 1 & (1.5) & 6 & $(8.8)$ & 0 & (0) & 0 & (0) & 0 & (0) & 4 & (5.9) & 13 & (19.1) & \\
\hline $\begin{array}{l}\text { Abdominal } \\
\text { pain }\end{array}$ & 1 & (1.5) & 2 & (2.9) & 0 & (0) & 0 & (0) & 0 & (0) & 1 & (1.5) & 4 & $(5.9)$ & \\
\hline Diarrhea & 0 & (0) & 1 & $(1.5)$ & 1 & $(1.5)$ & 0 & (0) & 0 & $(0)$ & 0 & (0) & 2 & (2.9) & \\
\hline $\begin{array}{l}\text { Threatened } \\
\text { abortion }\end{array}$ & 0 & (0) & 0 & $(0)$ & 0 & (0) & 0 & (0) & 1 & (1.5) & 0 & (0) & 1 & $(1.5)$ & 0.020 \\
\hline \multicolumn{16}{|l|}{ Drug intake } \\
\hline Hematinics & 2 & (2.9) & 9 & $(13.2)$ & 1 & $(1.5)$ & 5 & (7.3) & 0 & (0) & 5 & (7.3) & 22 & (32.4) & \\
\hline Antibiotics & 0 & (0) & 0 & (0) & 0 & (0) & 1 & $(1.5)$ & 0 & (0) & 2 & (2.9) & 3 & $(4.4)$ & \\
\hline Antimalaria & 1 & $(1.5)$ & 0 & (0) & 0 & (0) & 0 & (0) & 0 & (0) & 2 & (2.9) & 3 & $(4.4)$ & \\
\hline Franol & 0 & (0) & 1 & $(1.5)$ & 0 & (0) & 0 & (0) & 0 & (0) & 0 & (0) & 1 & $(1.5)$ & \\
\hline Primolute & 0 & (0) & 0 & (0) & 0 & (0) & 0 & (0) & 1 & (1.5) & 0 & (0) & 1 & $(1.5)$ & \\
\hline Don't know & 4 & (5.9) & 4 & (5.9) & 0 & (0) & 0 & (0) & 0 & (0) & 2 & (2.9) & 10 & (14.7) & 0.006 \\
\hline \multicolumn{16}{|c|}{ Traditional herbs } \\
\hline $\begin{array}{l}\text { Boiled } \\
\text { leaves }\end{array}$ & 1 & $(1.5)$ & 2 & $(2.9)$ & 0 & (0) & 3 & (4.4) & 1 & (1.5) & 1 & (1.5) & 8 & $(11.8)$ & \\
\hline $\begin{array}{l}\text { Herbs with } \\
\text { alc }\end{array}$ & 2 & (2.9) & 3 & (4.4) & 0 & (0) & 1 & (1.5) & 0 & (0) & 1 & (1.5) & 7 & $(10.3)$ & 0.649 \\
\hline \multicolumn{16}{|l|}{ Alcohol } \\
\hline Local gin & 3 & (4.4) & 2 & (2.9) & 0 & (0) & 2 & (2.9) & 0 & (0) & 2 & (2.9) & 9 & (13.2) & \\
\hline Beer & 1 & (1.5) & 1 & (1.5) & 1 & (1.5) & 1 & (1.5) & 0 & (0) & 2 & (2.9) & 6 & $(6.6)$ & \\
\hline Gin & 0 & $(0)$ & 1 & $(1.5)$ & 1 & $(1.5)$ & 0 & (0) & 0 & (0) & 1 & $(1.5)$ & 3 & $(4.4)$ & 0.772 \\
\hline
\end{tabular}


Although the overall prevalence of cleft lip with or without cleft palate has been reported to be commoner in males than females $(7,11-16)$, this study revealed the contrary with a slight female preponderance which was however not statistically significant $(\mathrm{p}$-value $=0.103)$. Similarly, isolated cleft lip was commoner in males than females this being similar to other study setting (13-19) as was isolated cleft palate in females as widely reported $(7,20-24)$.

While there has been no consensus on the most common type of cleft lip and palate (11,12,25-28), this study revealed combined unilateral cleft lip and palate as the commonest type of cleft in Benin City with no side predilection but commoner in males than females. A high prevalence of cleft palate either in isolation or in combination with cleft lip (75\%) was also noted in this study which agrees with reports from West Scotland, Northern Ireland and Finland $(21,22)$.

Varied literature (29-32) reports suggest that both genetic and environmental factors interact in the aetiology of orofacial clefts. This fact is clearly replicated in this study as family history is positively associated with the risk of cleft deformities in $13.2 \%$ of the study population which is in keeping with previously reported incidence of $10-20 \%$ (29). Lack of $100 \%$ genetic factor $(31,32)$ in the aetiology of cleft in twins was also identified in this study as only one each of all patients of multiple gestation in this study had cleft. This further gives credence to the fact that environmental factors play a significant role in the aetiology of orofacial cleft deformities. In fact, it is likely that environmental factors probably were the major agents at play in those twin patients that were seen in this study. Certainly further study in this regard is advocated. Although the highest incidence of genetic factor in cleft aetiology has been reported in females with bilateral clefts $(30,33)$ this study recorded a higher proportion of males with bilateral cleft lip and palate.

While the role of both maternal and paternal ages in the aetiopathogenesis of cleft remain contentious (3437), maternal and paternal ages greater than 35 years and 40 years respectively were observed as significant risk factors for the development of specific cleft types. Paternal age greater than 40 years is specifically more associated with isolated cleft palate $(\mathrm{OR}=2.33 \mathrm{CI}=1.52-3.25)$ in agreement with previous report by Bille et al (34). Likewise, maternal age greater than 35 years was significantly more associated with bilateral cleft lip and palate and unilateral left sided cleft lip and palate $(\mathrm{OR}=3.14$ $\mathrm{CI}=1.14-5.29 ; \mathrm{OR}=2.35 \mathrm{CI}=1.75-3.05)$ respectively.
Although the effect of socioeconomic class as an aetiologic factor in the development of cleft lip and palate is still in contention (29), well over half (69.1\%) of the study population came from low socioeconomic class. The exact import of ethnicity on the risk of development of cleft deformities in this study is not certain, even though it was noted that various ethnic groups were associated with different types of cleft. The Urhobo's of Delta State who made up the largest single ethnic group of this study commonly had unilateral left sided cleft lip and palate, unilateral right sided cleft lip and alveolus and bilateral cleft lip and alveolus. While amongst the other ethnic groups in Delta State, the commonly encountered cleft deformities were cleft palate, either in isolation or with cleft lip and alveolus. The reasons are inexplicable bearing in mind that all the ethnic groups live within same environmental milieu, have similar dietary pattern, alcohol intake and cultural norms. On the other hand, the Bini's who constituted the second largest ethnic group are more likely to have isolated cleft lip and bilateral cleft lip with bilateral cleft palate.

In keeping with existing data (38-40) on the impact of alcohol consumption on the risk of developing cleft deformities, a positive association was noted between alcohol intake and development of cleft palate with or without cleft lip in mothers who took alcohol occasionally or regularly. Also, it was noted that there was an increased risk of having a child with other congenital defects in mothers who drank alcohol during pregnancy especially syndactyly $(\mathrm{OR}=3.0$ CI 1.39-4.67) and congenital cardiac anomalies mainly ventricular septal defect, atrial septal defect and patent ductus arteriosus $(\mathrm{OR}=1.13$, $\mathrm{p}=0.011$ and $\mathrm{OR}=1.88$ ) respectively.

Cigarette and tobacco smoking are well documented risk factors for orofacial cleft (40-43). However, in this study there was no history of smoking in any form by the mothers of our cleft patients. But what gives an indication of the relationship between smoking and risk of developing cleft deformities in this study was the evaluation of the cooking method and the location of their kitchens. It was noted that there was an increased risk of unilateral left sided and bilateral cleft lip and palate $(\mathrm{OR}=1.70 \mathrm{CI}=1.69-3.42$; $\mathrm{OR}=1.42 \mathrm{CI}=1.02-2.40)$ respectively in those who cooked indoors as compared to those who did their cooking outdoors. The implication of this being that those who cooked indoors were more likely to have inhaled smoke from the cooking source that can be likened to cigarette smoking. An increased relative risk $(\mathrm{OR}=2.35 \mathrm{CI}=1.58-3.17)$ was also noted in isolated cleft palate and unilateral left sided cleft lip 
and palate $(\mathrm{OR}=1.08 ; \mathrm{CI}=1.39-2.94)$ in mothers who took herbal medications during their pregnancy.

The potential limitations of this study was the fact that part of the information/data collected were based on history from the patients and or their parents and therefore there was the possibility of concealing facts or information and indeed may even have recall bias. However, efforts were made to overcome this difficulty by counseling the patients/parents appropriately. The importance of volunteering accurate information/data was emphasized vis-à-vis the patient's management and identifying preventive strategies that will avoid a recurrence in future conceptions in the family. Additionally, efforts were made to determine the associated environmental risk factors for the development of clefts and not genetic factors, which was only indirectly inferred from the family history due to lack of facilities for DNA testing at both centers.

\section{Conclusion}

In conclusion, this study revealed that cleft lip and palate were a common encounter in clinical practice in Benin City. Orofacial cleft lip +/- palate were commoner in females than males. Factors associated with increased risk of developing cleft lip and palate were: paternal age $>40$ years, maternal age $>35$ years, genetic/family history, low socio-economic status, alcohol consumption and indulgence in the intake of herbal medications in pregnancy.

\section{Recommendation}

A larger country wide study to document a national prevalence of orofacial cleft and the associated factors in Nigeria is recommended. There is a need for public health education programmes to raise awareness on possible relationship between shown to be associated factors and development of cleft lip and palate.

\section{References}

1. Edward Ellis III. Contemporary Oral and maxillofacial surgery $4^{\text {th }}$ edition. Mosby Inc. 2003. Management of patients with orofacial clefts. $623-645$.

2. Tessier P Anatomical Classification of facial, craniofacial and laterofacial clefts. J maxillofac Surg 1976; 4:69

3. Sadler TW. Langman's Medical embryology. $9^{\text {th }}$ Edition. Lippincott Williams and Wilkins Head and Neck 2004; 363 - 401.

4. Badoe Archampone, Jaja. Principles and practice of surgery $2^{\text {nd }}$ edition Ghana Publishing Co-operation. Plastic Surgery 1986; 237-246.
5. Iregbulem LM. The incidence of cleft lip and palate in Nigeria. Clef Palate J 1986; 19:201205

6. Orkar K.S, Ugwu BT, Momoh JT. Cleft lip and Palate: The Jos Experience. East Afr. Med. 2002; 79:509.

7. Obuekwe O.N, Akpata O. Pattern of cleft lip and palate (corrected) in Benin City, Nigeria. Cent Afr J Med 2004; 50: 65-69.

8. Taylor DW. The calculation of sample size and power in the planning of experiments. Department of clinical epidemiology and biostatistics Mc Master University, Hamilton, Ontario Canada 1994.

9. Srivastava S, Bang RL. Facial Clefting in Kuwait and England: A comparative study. $\mathrm{Br}$. J. Plast. Surg. 1990; 43:457-462

10. Zlotogora. Genetic disorders among Palestinian Arabs: i. Effects of consanguinity. Am J Med Gene. 1997; 68: 472-475.

11. Elahi MM, Jackson IT, Elahi O, Khan A, Mubarak F, Tariq G, Miltra A. Epidemiology of cleft lip \& palate in Pakistan. Plastic \& Reconstructve Surgery 2004; 113:1548-1555.

12. Ugboko V, Owatade F, Otuyemi O, Adejuyigbe O. Experience with cleft lip and palate patients seen in a Nigerian Teaching Hospital. Pediatric Dental Journal 1997; 7: 4144.

13. Fogh_Andersn P. Inheritance of cleft lip and cleft plate. Copenhagen. 1942: Arnold Busck

14. Bonaiti C, Briard ML, Feingold J, Pavy B, suame J, Migrie-Lufferaud G, Kaplan J. An epidemiological and genetical study of facial clefting in France. Epidemiology and frequency in relatives. J Med Genet 1982; 19:8-15

15. Calzolari E, Milan M, Cavazzuti GB, Cocchi G, Gandini E, Magnani C, Moretti M, Garani GP, Solvioli GP, Volpato S. Epidemiological and genetic studies of 200 cases of oral clefts in the Emilia Romangna region in region of Northern Italy. Teratology 1988; 38:559-564

16. Adekeye EO, Lavery KM. Cleft lip and palate in Nigerian children and adults: a comperative study. Br. J Oral Maxillofac Surg 1985; 23:398-403

17. Bellis TH. Incidence of cleft lip and palate deformities in South East Scotland, 1971-1990

Br. J. Orthodontics 1999; 26:121-125

18. Fitzpatrick, D.R, Raine PAM and Boorman J.G. Facial clefts in the West of Scotland in the period 1980-1984: Epidemiology and genetic diagnosis. Journal of Medical Genetics 1994; 31:126-129. 
19. Greg T. Boyd D and Richardson A. The incidence of cleft lip and palate in Northern Ireland 1980-1990. Br. J. of Orthodontics 1994; 21:387-392

20. Carinci F, Rullo R, Farina A, Morano D, Festa VM, Mazzaralla N, DelViscovo D, Carls PF, Becchetti A, Gombos F. Nonsyndromic orofacial clefts in Southern Italy: pattern analysis according to gender, history of maternal smoking, folic acid intake and familial diabetes. Craniomaxillofac Surg. 2005; 33:91-94.

21. Datubo-Brown DD and Kejeh BM. Pattern of cleft lip and palate deformities in Rivers State of Nigeria. J. Pak Med Assoc 1996; 40:64-66

22. Rajabian $\mathrm{MH}$, Sherkat $\mathrm{M}$. Epidemiologic study of oral clefts in Iran: Analysis of 1669 cases. Cleft Palate - Cranofacial Journal 1999; 37:191-196

23. Fraser F.C. The genetics of cleft lip and palate. Am J Hum Genet 1970; 23:336-352

24. Talarova MM. Cleft lip and palate. eMedicine - Cleft Lip and Palate: Article by Marie M Talarova 2006.

25. Murray JC. Gene / Environment causes of cleft lip and/or palate. Clin Genet 2002; 61:248 256.

26. Stanier P and Moore GE. Genetics of cleft lip and palate: syndromic genes contribute to the incidence of non-syndromic clefts. Human Molecular Genetics 2003; 13:73-81.

27. Fraser FC. Thoughts on the etiology of clefts of the lip and palate. Acta Genet 1955; 5:358469.

28. Bille C, Skytte A, Vach W, Knudsen LB, Andersen AM, Murray JC, Christensen K. Parent's age and risk of oral clefts. Epidemiology 2005; 16: 311-316.

29. Vieira AR, Orioli IM, Murray JC. Maternal age and oral clefts: a reappraisal. Oral Surg Oral Med Oral Pathol Oral Radiol Endod. 2002; 94: 530-535.

30. DeRoo LA, Gaudino JA, Edmonds LD. Orofacial cleft malformations: associations with maternal and infant characteristics in Washington State. Birth Defects Res A Clin Mol Teratol 2003; 67: 637-642.

31. Sipek A, Gregor V, Horacek J, Masatova D. Facial clefts from 1961-2000 — incidence, prenatal diagnosis and prevalence by maternal age. Ceska Gynekol 2002; 67:260-267.

32. Werler MM, Lammer EJ, Rosenberg L, Mitchell AA. Maternal alcohol use in relation to selected birth defects. Am J Epidemol 1991; 34:691-8.

33. Shaw GM, Lammer EJ. Maternal periconceptional alcohol consumption and risk for orofacial clefts. J Pediatr 1999; 134:298303.

34. Munger RG, Romitti PA, Daack-Hirsch S, Burns TL, Murray JC, Hanson J. Maternal alcohol use and risk of orofacial cleft birth defects. Teratology 1996; 54:27-33

35. Khoury MJ, Gomez-Farias M, Mulinare J. Does maternal cigarette smoking during pregnancy cause cleft lip and palate in offspring? Am J Dis Child 1989; 143:333-337.

36. Shaw GM, Wasserman EJ, Lammer EJ, O’Malley CD, Murray JC, Basart AM, Tolarova MM. Orofacial clefts, parental cigarette smoking, and transforming growth factor-alpha gene variants. Am J Hum Genet. 1996; 58:551-561.

37. Christensen K, Olsen J, Norgaard-Pedersen B, Basso O, Stovring H, Milhollin-Johnson L, Murray JC. Oral clefts, transforming growth factor alpha gene variants, and maternal smoking: a population-based case-control study in Denmark, 1991-1994. Am J Epidemiol. 1999; 149:248-255.

38. Chung KC, Kowalski CP, Kim HM, Buchman SR. Maternal cigarette smoking during pregnancy and the risk of having a child with cleft lip/palate. Plast Reconstr Surg 2000; 105:485-491.

39. Lorente C, Cordier S, Goujard J, Ayme S, Bianchi F, Calzolari E, DeWalle HE, KnillJones R. Tobacco and alcohol use during pregnancy and risk of oral clefts. Occupational Exposure and Congenital Malformation working group. Am J Public Health 2000; 90:415-419.

40. Deacon S. Maternal smoking during pregnancy is associated with a higher risk of non-syndromic orofacial cleft in infants. Evid Based Dent 2005, 82(3):213-218.

41. Little J, CardyA, MungerRG. Tobacco smoking and oral clefts: a meta-analysis. Bull World Health Organ 2004; 82:213-218. 